\title{
Tourism and transformation: Negotiating metaphors, experiencing change
}

Sofia Sampaio ${ }^{1}$, Valerio Simoni ${ }^{2}$ and Cyril Isnart $^{3}$

\section{Tourism as an exogenous force: 'impact studies'}

The notion of 'transformation' has been a constant preoccupation in social science studies of tourism. In her editorial introduction to the classic Hosts and Guests: The Anthropology of Tourism (1978), Valene Smith famously defined the tourist as 'a temporarily leisured person who voluntarily visits a place away from home for the purpose of experiencing change' (Smith, 1978, p. 2, our emphasis). A landmark of tourism anthropological studies, this book was mostly concerned with the 'effects' of tourism on 'the people involved' (Smith, 1978: 1). As Smith put it: 'Tourism is a powerful medium affecting culture change, and central to its anthropological study is the impact between hosts and guests' (p. 3). In the book, the impacts considered ranged from the economic (Greenwood, 1978) and cultural (Nash, 1978) to the interpersonal (Pi-Sunyer, 1978).

Despite accentuated differences between them, and a shared concern with cultural issues, contributors tended to foreground economic factors, equate tourism with 'the tourism industry' (p. 15), and favour the point of view of the 'hosts'. Most authors were interested in the effects of tourism on living standards of the locals; native industries (especially the arts and crafts); and traditional values and concepts of self and 'Other.' Tourism was thus conceived of as an exogenous force, i.e. as an ensemble of socioeconomic structures and lifestyles that originate outside the community, impinging on it in various ways, and thus being endowed with great transformational power. It followed that tourists were widely perceived as agents of change, but not as subjects of change. In other words, they could exert change, even if unwittingly, on other places and communities, but they themselves would not undergo change. Curiously, the latter possibility had been spelled out in Smith's definition of tourist, quoted above, but did not seem worthy of much consideration (but see below Graburn, 1978).

The 'impact studies' line of tourism anthropology was stranded in either casuistic approaches or grand theorisation, advancing the case of tourism either as a general beneficial force or as social evil. As Crick (1989) noted, most anthropological and sociological studies would tend to adopt the latter stance, and to assess rather negatively the sociocultural changes brought by tourism. This observation was confirmed by Stronza (2001) a decade later, in another review article on the anthropology of tourism. What is more, Stronza considered that even in the more positive evaluations of

\footnotetext{
${ }^{1}$ Centre for Research in Anthropology (CRIA), Instituto Universitário de Lisboa, Lisbon, Portugal,psrss@iscte.pt

${ }^{2}$ Centre for Research in Anthropology (CRIA), Instituto Universitário de Lisboa, Lisbon, Portugal, vals_sim@yahoo.com

${ }^{3}$ CIDEHUS, Universidade de Évora, Évora, Portugal, isnartc@gmail.com
} 
tourism's impacts, notably those considering recent developments in 'alternative forms of tourism' (Stronza 2001, pp. 275-276), '[t] he emphasis remains (...) on what is external to a site' (p. 275), and overlooks the more active and reflexive dimensions of local communities' engagements with tourism. Crick's intervention was already pointing in that direction, as it urged to pay more attention to 'local perceptions and understandings of tourism' and, even more relevant for this special issue, to 'the local perceptions of change and continuity' (1989, p. 338). If this anthropologist called for more 'detailed work' on 'what the particular mechanisms of change are' (Crick, 1989, p. 336), the point of Stronza's review was also to encourage more studies on the effects of tourism on those who travel, on how tourism may create 'truly transformative experiences for tourists' (2001, p. 261), and thus highlighted another key dimension of tourism and transformation that lies at the heart of this special issue.

\section{The 'changing' tourist: the transformation of the 'tourist self'}

One notable exception to the 'impact study' trend in the Hosts and Guests collection was Nelson Graburn's contribution, which overtly addressed the issue of the tourist as a subject of change. Graburn drew on Durkheim's and Mauss's ideas on the alternation of ordinary (or profane) and nonordinary (or sacred) states in modern life, to locate tourism in the latter sphere, stressing its meaning-adding (p. 17) and value-adding (p. 23) qualities. Using the first person plural (unafraid to close down the gap between tourists and anthropologists), Graburn concluded that upon their return, tourists no longer were their former selves: 'We are a new person who has gone through recreation and, if we do not feel renewed, the whole point of tourism has been missed' (Graburn, 1978, p. 23). Transformation is thus introduced as an important and, indeed, intrinsic part of the tourist experience: either the tourist experience changes the tourist or it is not a tourist experience at all (see also Graburn,1983).

The issue of transformation as essential part of the tourist experience did not attract further attention and investigation in the succeeding years. As Bruner's article on tourism and transformation (1991) would later confirm, the notion that the tourist could be transformed through tourism had been a staple of the rhetoric of the tourism industry, being rife in tourism promotional literature like brochures and advertisements, as well as travel writing. Bruner's article was especially concerned with the discrepancy between a rhetoric which hyperbolically promised the tourist 'a total transformation of self' (1991, p. 239) and the tourist's actual experience. Focusing on tourism to Africa, he argued that the promise of change aimed at the tourist was underpinned by another promise: that the 'native self' would remain unchanged, which implicitly posited it as unchangeable (p. 240). In a deconstructive and somewhat provocative gesture, Bruner went on to make the opposite claim, namely: 'that the tourist self is changed very little by the tour, while the consequences of tourism for the native self are profound' (p. 242).

This closeness between the metaphor of the tourist's transformation and the language and imagery of the tourism industry might have discouraged researchers from 
delving deeper into the topic. In drawing attention to this connection, Bruner's article made important headway. This author's major contribution was, no doubt, the recognition that tourist narratives and discourses organise and give meaning to tourist experiences (p. 240). The focus of this article, it should be noted, was confined to the context of power inequalities between the West and 'the rest', rather than 'the individual tourist' (p. 247). However, at the close of his article, Bruner admits that a more 'moderate or intermediate position' should be tested in future studies (p. 248), which, at the time, seemed a promising prospect.

Another important study that warranted special attention to change was International Tourism: Identity and Change (1995), a collection of essays edited by Marie-Françoise Lanfant, John B. Allcock and Edward M. Bruner, which grew out of the collaboration of researchers connected to the International Sociological Association. In the introduction, Lanfant is clear about the authors' desire to distance themselves from 'impact studies', rejecting the idea of tourism as an 'exogenous force' (p. 1; p. 5). As the title suggests, the volume focuses on questions of identity and change within an understanding of 'tourism' as an international phenomenon, in which the local and the global are intertwined under the shaping influence of 'globalization' (the watchword for the nineties, if there was any). Considered as 'a powerful lever for social change' (p. 6), tourism is especially active in triggering or facilitating identity affirming processes, such as those involving nation-states, which must nevertheless be followed at a local level and described from a local perspective. Rejecting the idea of a 'monolithic' tourist system, the authors stress the role of local actors and, by extension, the variety and complexity of these 'processes of constructing, deconstructing and reconstructing identity', showing a special interest in the way actors experience these processes subjectively, as well as 'objectively and rationally' (p. 7).

This proposal can be seen as an invitation to further empirical and ethnographic work. A seminal work like Dean MacCannell's The Tourist: A New Theory of the Leisure Class $(1976 ; 1999)$ had been key in shifting attention to tourists, rather than their 'impacts', even if its main motivation had been to explore the tourist as a stand-in for the modern man (rather than woman, as later critics would point out - e.g. Pritchard and Morgan, 2000), i.e. to produce abstract theories that drew upon and reinforced a set of structural dualisms (ordinary: extraordinary; work: leisure; home: away, etc.) which would be enough to explain a variety of tourist contexts and situations. This focus on 'grand theorising' would be one of the major critiques levelled against the 'first wave' sociology of tourism (Franklin, 2009), of which MacCannell's work and John Urry's The Tourist Gaze (1990; 2002) were the major exponents. As these theories gained currency, ethnographies of tourists began to appear, shedding light on the plurality and complexity of motivations, expectations and experiences associated with being a tourist. Despite the difficulties involved in studying actual tourists (cf. Leite \& Graburn, 2009), there is no doubt that ethnographic methods have paid off, leading up to more challenging questions and theoretical renovation, opening up new research paths, and 
generally resulting in a greater understanding of the processes intrinsic to or associated with tourism.

\section{The multiplication of objects of transformation}

With the dramatic expansion of tourism studies, in keeping up with the expansion of tourism itself over the past few decades, new subjects and approaches have emerged. The proliferation of tourist attractions and experiences (new 'global' cities and trendy neighbourhoods; 'voluntourism'; 'roots' and 'homeland' tourism; 'reproductive tourism'; 'thanatourism'; etc.) has meant the proliferation of subjects and objects of transformation. Change can happen at many levels, from host societies and touristgenerating areas (though the latter have received less attention) to individuals, places and discourses. Topics like the transformation of places into tourist sites (and into tourist 'markers' - cf. Urry, 2002) and the preservation (or invention) of traditional identities through heritage-driven or ethnicity-based cultural tourism have become classics in tourism studies (e.g. Bendix, 1989; Boissevain, 1996; Picard, 1996). Recent trends have tried to recuperate the everyday, ordinary and banal dimensions of tourism (e.g. Löfgren, 2008), in addition to its more often addressed 'out of the ordinary' and exotic elements; to assign more importance to the tourist body (e.g. Veijola \& Jokinen, 1994), which had been previously ignored by an 'ocularcentric' tradition of tourism studies; and to redirect research to the performance of meanings (rather than just their representation) (e.g. Coleman \& Crang, 2002).

It has become a cliché to state that tourism has spilled over from its relatively restricted field of action (if there ever was one) to become 'a significant modality through which transnational modern life is organized' (Franklin \& Crang, 2001, pp. 67). If claims that we have all now become tourists may sound excessive (being useless for analytical purposes), there is no doubt, as Leite and Graburn have suggested, that the study of tourism can act as a 'point of entry' into some of the most pressing of presentday research topics, such as those involving mobilities and flows of various kinds (from people to things, images and ideas - not to mention capital), as well as global-local, national-transnational interconnections (2009, pp. 46, 52, 54). In fact, even when we do not directly engage in tourism, the touristic is likely to mediate our relationship with the world, through a rather pervasive tourist imaginary and 'desire'.

The role that images, metaphors, myths and narratives have played in shaping tourism and tourist practices has long been acknowledged and scrutinised (e.g. Selwyn, 1996). Research on literary tourism (e.g. Robinson \& Andersen, 2002) has more recently been followed by an interest in the variety of intersections between tourism and electronic media like films, television and the Internet, leading some scholars to speak of a new field of studies, 'tourist media studies' (Mazierska \& Walton, 2006, p. 10). Concepts like the 'tourist imagination' (Crouch, Jackson \& Thompson, 2005), the 'tourist gaze' turned 'mediatised gaze' (Edensor, 2005, p. 105) and 'virtual travel' have been used as theoretical tools to explore the perceived convergences of tourism and the 
media. Through the media, viewers come into touch with a wealth of travel-related narratives - of which the journey-as-transformation narrative is but one - which will flow into their 'virtual' or actual tourist experiences. But it is not as though such narratives are simply taken in, conforming to an attitude of passivity, which has, indeed, been associated with both spectators and tourists (Crouch et al., 2005, p. 5; Davin, 2005). Following one of the key lessons of media audience studies - that there is always a 'lacuna' between a text and its audiences (cf. Crouch et al., 2005, p. 11) - people confront media texts both as viewers and as tourists, negotiating narratives and metaphors in face of their own experiences of travel and change. The reception of these texts deserves closer attention, in line with the other emerging objects and theoretical trends noted above. Especially relevant is Franklin and Crang's call for more research on 'the sensual, embodied and performative dimensions of change in tourism cultures' (2001, p. 14).

Finally, there is also the transformation of concepts. This aspect is frequently neglected or downplayed in a field that is so prone to lapse into static, self-perpetuating and a-historical concepts and perspectives. Historian John K. Walton has deplored the 'present-mindedness and superficiality' that dominates tourism studies (2005, p. 6) while others (e.g. Franklin and Crang, 2001) have noted the ossification of concepts and theories, despite the wealth of in-depth case studies that have emerged over the past few years. An example is the much-influential concept of 'tourist gaze,' which has been criticised for its a-historicity, even if its major theorist, British sociologist John Urry, did mention the need to attend to its 'historical transformations' (Urry, 2002, p. 3). Being active in historical processes in their own right, theories and concepts are subject to change and are therefore in need of constant reformulation and updating.

\section{Our contribution: the performativity and reflexivity of 'transformation'}

This collection of articles stems from the recognition that while much has been written about transformation in tourism, there is still very little literature in the way of a systematic overview of this subject. Too many questions remain unanswered and the terms of the debate have seldom been as reflexive as they should have been. Hence, it is our major concern to formulate, even if not necessarily to answer, some of these questions: What is the dialectic between the expectation of transformation and the performativity of the transformation rhetoric? When do people speak about transformation, and what comes to count as such? Where do the rhetoric and models of transformation originate, and what has been the role of social scientists in their formalisation and diffusion? Who is deploying this notion and to what ends? What kind of phenomena does the rhetoric of transformation highlight, and what does it obscure? Which are the struggles, negotiations, and appropriations that the issue of transformation generates? What does the preoccupation and engagement with tourismrelated transformations reveal about broader societal concerns with identity, heritage, and development? 
The focus of our attention is, clearly, how social actors have appropriated, negotiated, used, narrated and 'changed' transformation - what we could call the performativity of transformation. The trend in many studies (even if unwittingly or in unformulated ways) has been to assume that there is an ideological social sphere as opposed to a non-ideological one. Lanfant, for instance, speaks of the need to distinguish 'between a desire to construct identities which is basically motivated by ideology, and those identities which emerge naturally from the working of societies' (Lanfant, 1995, p. 4, our emphasis). This distinction strikes us as less than obvious, as what is regarded as 'ideology' and what is regarded as 'natural' are more often than not difficult to tell apart (in fact, ideology is most powerful when it manages to define what should pass off as 'natural'). More important than to draw this line, in our view, is to recognise the power and efficacy that a concept like 'transformation' holds or attains in tourist contexts, how it is addressed, dissected, broken down, reassembled, and made operational. Indeed, apart from being a worn-out cliché that circulates in tourism advertising, travel writing and other media (not least, in feature films, as Sofia Sampaio's contribution to this special issue demonstrates), the notion of travel as a source of transformation is subject to several kinds of appropriation and negotiation, being manipulated to suit different aims.

If this kind of 'appropriation' makes for the first level of our analysis, the second one is reflexivity. Franklin and Crang have stressed the need to reconnect tourism studies with 'the lay and popular knowledges produced through tourism', or what these authors also call 'the "doing-knowledge" of tourists' (2001, p. 8). What is remarkable about the notion of transformation, especially in the form of the travel-as-transformation trope, is the way it seems to be ubiquitous and self-evident, being frequently invoked, but also the way it is so often resisted to and rejected, or made to incorporate a wealth of variations, with some degree of reflexivity. As Dionigi Albera, Valerio Simoni and Anna Fedele suggest, in their contributions to this issue, anthropological and sociological theories of tourism and pilgrimage have long crossed over the walls of academia. We cannot expect tourists not to be knowledgeable of concepts like 'authenticity', 'commodification', 'sex tourism' and 'transformation', which they often deploy ironically or in self-reflexive earnestness. Rather than seeing in it a sign of a lost innocent era, when researchers 'knew better' than their interlocutors, we should regard this development as worthy of our attention and thoughtful consideration. 'Lay' and popular knowledges of what tourism and transformation are or should be about have similarly permeated our scientific inquiry. Apart from being social scientists we are also readers of travel books, viewers of travel films, users of the Internet - not to mention, tourists. The 'doing-knowledge' of tourists and the academic theories of tourism (often popularized through mainstream literature) flow around in a turbulent two-way circle, merging, feeding each other, struggling to set new boundaries and establish new distinctions between themselves.

\section{Authors' contributions}


The articles in this collection address these questions through a variety of interdisciplinary perspectives (anthropology, history, social theory and cultural studies) and empirical case studies stretching geographically from the Mediterranean (Rhodes, Italy, Portugal, France) to the Americas (Cuba and the U.S.), and reaching out to the transnational and hyper-mediated spaces of film viewing and Internet blogging. By focusing on the issue of transformation at the different and complementary levels of place, people and concepts, the contributions unpack a wide range of narratives and practices of change in tourism.

There is no doubt, as John K. Walton has suggested, that history, as a discipline and a method, has an important contribution to make to the understanding of tourism as a dynamic and transformative process (2005, p. 1). Dionigi Albera's and Frédéric Vidal's articles are especially illustrative of this point. Albera offers us a longitudinal study of a festive performance, the Baì of Sambuco, in the Piedmontese Alps, from the eighteenth-century to our days, focusing on the 'tradition-freezing' process that took place at the beginning of the twentieth century in response to deep social, economic and demographic changes. The author demonstrates how elements of innovation and continuity are brought together in a performance that, though conceived as a bulwark against unwelcome transformations and as a relatively closed-in community affair, has not managed to avoid becoming a 'show' for 'outsiders' (a very open category that includes migrants, roots pilgrims, tourists, ethnographers, among many others) or taking on new roles and meanings (namely, political ones).

Vidal's historical study of Alcântara, a neighbourhood situated in Lisbon's West End, provides a detailed account of the role that tourist practices and perceptions played in the long process that saw this part of the city be recognised as an urban space, integrated within the city's administrative boundaries (but not immediately on its maps), and made to evolve from a working class to a popular neighbourhood. Vidal thus demonstrates 'the durable transformative potential of travel and tourism in the formation of modern conceptions about urban space, urban sociability, and leisure', fully justifying the benefits of bringing together urban history and the history of tourism.

Cyril Isnart's research on the appropriations of tourist practices by a Catholic religious minority in Rhodes adds a new chapter to the long line of studies that connect tourism with the preservation of local identities (of which Albera's case study might be another example). What Isnart describes, however, is a rather different process. He draws attention to the changes that the local priest (the island's major Catholic authority) and his close staff have introduced in everyday practices and liturgical rituals in an effort to address the on-going changes brought about by the intensification of tourism on the island, but also to recuperate elements of continuity with the diverse layers of Rhodes' Catholic past. The author thus arrives at the claim that change can be used to keep things unchanged (hence the more than appropriate quote from Luchino Visconti's Il Gattopardo that introduces this article), and vice versa. 
The contributions of Anna Fedele and Valerio Simoni are more concerned with transformation on an experiential and personal level. In her ethnography of alternative pilgrims to Catholic shrines, Fedele argues that the concept of personal transformation, in articulation with an energy language (e.g. 'power places' and 'energy body'), was crucial for her interlocutors to distance themselves from identities and practices traditionally associated with these places, in order to carve meanings more conforming to their own 'spiritual quests'. In this process, perhaps surprisingly, the term 'tourist' is often preferred to that of 'pilgrim', due to the latter's Christian (and patriarchal) associations. As it happens, 'spiritual travellers' show no qualms in taking up typical tourist or mundane activities (like buying a souvenir or going to a spa) which they then 'reframe' with an 'energy language' that posits them as a means to gain 'spiritual insight' or attain personal 'healing'.

Drawing on extensive fieldwork in Cuba, Simoni addresses experiences and notions of transformation in touristic sexual contexts. His question is, basically, how male tourists work over narratives of Cuban sexuality that dominate media and tourism representations as a result of their engagements with actual Cuban women, i.e. how 'relational idioms are acted upon and transformed in concrete - and often very ambiguous - moments of interaction'. Capturing a wide range of nuances that are habitually buried under the overarching term of 'sex tourism', the author uncovers four main approaches to sexual encounters: 'ethical restraint', 'adaptive normalization', 'first contact' and 'sex tourism'. In each of these he explores how male tourists resort to narratives of transformation (of themselves, of Cuban women, of Cuba) to justify their attitudes and practices and enact specific kinds of subjectivities, moralities, and power relations.

The pervasiveness of the media (in particular, travel literature, films and the Internet) and the way they influence our tourist perceptions and practices takes central stage in our last contribution, Sofia Sampaio's article. The author examines the reviews of two popular films, The Beach (2000) and The Motorcycle Diaries (2004), posted on the Internet Movie Data Base (IMDB), to determine how viewers have received these films' main proposition - that the protagonists have undergone a life-changing experience during their journeys. The multiple, often-contradictory readings suggest that the viewers' responses are shaped by their travel expectations (often derived from their travel experiences), but also by their narrative expectations, which are especially indebted to an (implicit or explicit) understanding of a film as synonymous with a classical narrative structure. The article shows how widespread and meaningful the travel-as-transformation trope is. It also proves that there is no straight correspondence between mainstream discourses and representations, on the one hand, and the viewer's responses and practices, on the other. This kind of indeterminacy makes the study of media representations and mediated experiences of transformation difficult, but all the more interesting and challenging.

One question that all the contributors, directly or indirectly, raise concerns the way transformation is to be studied and grasped. Frédéric Vidal notes the downsides of 
drawing exclusively on texts and archival sources, which may have failed to record feelings and experiences that we would find relevant today. He also draws attention to the difficulty in telling apart which transformations we are trying to describe or dealing with - transformations of discourses, of perceptions, of their uses? Referring explicitly to her interlocutors' claims to having undergone some kind of transformation, Fedele stresses the difficulties in accessing the intricacies of the 'inner journey', as transformation is often experienced as an inner process. Simoni puts the stress on 'what counts as transformation' for the people, and for what practical effects, since what is being transformed and how are themselves objects of contention and Isnart proposes the development of 'an ethnography of the consciousness of transformation.'

All this makes the study of transformation in tourism an elusive project. Yet, as this special issue hopes to demonstrate, there are advantages in tackling this subject holistically, as part of a rich network of concepts, words, discourses and practices that the protagonists of tourism deploy, appropriate and adapt to their needs and desires. Taken together, all the contributions included in this issue show how the very concept of transformation can be fruitfully apprehended as a moving notion that is purposefully deployed by people and social groups involved in tourism - a way for them to make sense, take a stance, act upon, and also benefit from it. Ultimately, the collection marks a significant step to re-open and reconceptualise the issue of transformation in tourism, and provides new insights into how experiences-turned-metaphors and metaphorsturned-experiences influence both the travel experience and the development of theory.

\section{Acknowledgements}

This collection of articles stems from the International Symposium, 'Sacred Tourism, Secular Pilgrimage: Travel and Transformation in the 21st Century', held in Lisbon in July 2011 and hosted by the Centre for Research in Anthropology (CRIA) and the Instituto Universitário de Lisboa (ISCTE-IUL), which was organised by Sofia Sampaio, Cyril Isnart and Anna Fedele. We wish to thank all the other participants - Nelson Graburn, Ellen Badone, Maria Cardeira da Silva, Antonio Miguel Nogués-Pedregal, David Picard, Katia Boissevain and Ema Pires - for their precious contribution to this stimulating meeting. We would also like to acknowledge the financial support (FACCFCT 2011-1-690) of the Portuguese national funding agency for science, research and technology (FCT), which enabled the realisation of this event. Finally, special thanks are due to Nelson Graburn and Josef Ploner for their useful comments on this introduction.

\section{References}

Bendix, R. (1989). Tourism and Cultural Displays: Inventing Traditions from Whom? Journal of American Folklore, 102, 127-146. 
Boissevain, J. (Ed.). (1996). Coping with Tourism. European Reactions to Mass Tourism. Providence/Oxford: Berghahn Books.

Bruner, E.M. (1991). Transformation of Self in Tourism. Annals of Tourism Research, $18,238-250$.

Coleman, S. \& Crang, M. (Eds.) (2002). Tourism: Between Place and Performance. New York and Oxford: Berghahn Books.

Crick, M. (1989). Representations of Tourism in the Social Sciences: Sun, Sex, Sights, Savings, and Servility. Annual Review of Anthropology, 18, 307-344.

Crouch, D., Jackson R. \& Thompson, F. (2005). The Media and the Tourist Imagination: Converging cultures. London and New York: Routledge.

Davin, S. (2005). Tourists and television viewers: some similarities. In D. Crouch, R. Jackson \& F. Thompson (Eds). The Media and the Tourist Imagination: Converging cultures (pp. 170-182). London and New York: Routledge.

Edensor, T. (2005). Mediating William Wallace: Audio-visual technologies in tourism. In D. Crouch, R. Jackson \& F. Thompson (Eds). The Media and the Tourist Imagination: Converging cultures (pp. 105-118). London and New York: Routledge.

Franklin, A. (2009). The Sociology of Tourism. In T. Jamal \& M. Robinson (Eds). The Sage Handbook of Tourism Studies (pp. 65-81). Los Angeles and London: Sage.

Franklin, A. \& Crang, M. (2001). The Trouble with tourism and travel theory? Tourist Studies, 1(1): 5-22.

Graburn, N. (1978). Tourism: The Sacred Journey. In V.L. Smith (Ed.). Hosts and Guests: The Anthropology of Tourism (pp. 17-31). Oxford: Basil Blackwell.

Graburn, N. (1983). The Anthropology of Tourism. Annals of Tourism Research, 10(1), 9-33.

Greenwood, D.J. (1978). Culture by the Pound: An Anthropological Perspective on Tourism as Cultural Commoditization. In V.L. Smith (Ed.). Hosts and Guests: The Anthropology of Tourism (pp. 129-138). Oxford: Basil Blackwell.

Lanfant, M.-F. (1995). Introduction. In M.-F. Lanfant, J.B. Allcock, E.M. Bruner (Eds). International tourism: identity and change (pp. 1-23). London : Sage Publications and International Sociological Association.

Lanfant, M.-F., Allcock, J.B. \& Bruner, E.M. (Eds) (1995). International tourism: identity and change. London: Sage Publications and International Sociological Association. 
Leite, N. \& Graburn, N. (2009). Anthropological Interventions in Tourism Studies. In T. Jamal \& M. Robinson (Eds). The Sage Handbook of Tourism Studies (pp. 35-64). Los Angeles and London: Sage.

Löfgren, O. (2008). The Secret Lives of Tourists: Delays, Disappointments and Daydreams. Scandinavian Journal of Hospitality and Tourism, 8(1): 85-101.

MacCannell, D. (1999) [1976]. The Tourist: A New Theory of the Leisure Class. Berkeley: University of California Press.

Mazierska, E. \& Walton, J.K. (2006). Tourism and the moving image. Tourist Studies, 6(1): 5-11.

Nash, D. (1978). Tourism as a Form of Imperialism. In V.L. Smith (Ed.). Hosts and Guests: The Anthropology of Tourism (pp. 33-47). Oxford: Basil Blackwell.

Picard, M. (1996). Bali: Cultural Tourism and Touristic Culture. Singapore: Archipelago Press.

Pi-Sunyer, O. (1978). Through Native Eyes: Tourists and Tourism in a Catalan Maritime Community. In V.L. Smith (Ed.). Hosts and Guests: The Anthropology of Tourism (pp. 149-155). Oxford: Basil Blackwell.

Pritchard, A. \& Morgan, N. (2000). Privileging the Male Gaze: Gendered Tourism Landscapes. Annals of Tourism Research, 22(2): 422-440.

Robinson M. \& Andersen, H. C. (Eds). (2002). Literature and Tourism: Essays in the reading and writing of tourism. London: Thomson.

Selwyn, T. (Ed.) (1996). The Tourist image: myths and myth making in tourism. Chichester, New York: John Wiley.

Smith, V.L. (Ed.) (1978). Hosts and Guests: The Anthropology of Tourism. Oxford: Basil Blackwell.

Stronza, A. (2001). Anthropology of Tourism: Forging New Ground for Ecotourism and Other Alternatives. Annual Review of Anthropology, 30, 261-283.

Urry, J. (2002) [1990]. The Tourist Gaze Second Edition. London, Thousand Oaks, New Delhi: Sage.

Veijola, S., \& Jokinen, E. (1994). The body in tourism. Theory Culture \& Society, 11(3): 125-151.

Walton, J.K. (2005). Introduction. In J.K. Walton (Ed.). Histories of Tourism: Representation, Identity and Conflict (pp. 1-18). Clevedon: Channel View Publications. 